\title{
Malaysian Siblings with Friedreich Ataxia and Chorea: A Novel Deletion in the Frataxin Gene
}

\author{
Siân D. Spacey, Blazej I. Szczygielski, Sean P. Young, Juliette Hukin, \\ Kathy Selby, Terrance P. Snutch
}

\begin{abstract}
Background: Friedrich ataxia (FRDA1) is most often the result of a homozygous GAA repeat expansion in the first intron of the frataxin gene (FRDA gene). This condition is seen in individuals of European, North African, Middle Eastern and Indian descent and has not been reported in Southeast Asian populations. Approximately 4\% of FRDA1 patients are compound heterozygotes. These patients have a GAA expansion on one allele and a point mutation on the other and have been reported to have an atypical phenotype. Objective: To describe a novel dinucleotide deletion in the FRDA gene in two Malaysian siblings with FRDA1. Setting: Tertiary referral university hospital setting. Patients and Methods: A previously healthy 10-year-old Malaysian boy, presented with fever, lethargy, headaches, dysarthria, dysphagia, vertigo and ataxia which developed over a one week period. His neurological exam revealed evidence of dysarthria and ataxia, mild generalized weakness and choreoform movements of the tongue and hands. His reflexes were absent and Babinski sign was present bilaterally. A nine-year-old sister was found to have mild ataxia but was otherwise neurologically intact. Results: Molecular genetic studies demonstrated that both siblings were compound heterozygotes with a GAA expansion on one allele and a novel dinucleotide deletion on the other allele. Conclusions: We describe a novel dinucleotide deletion in the first exon of the FRDA gene in two siblings with FRDA1. Additionally this is the first report of FRDA1 occurring in a family of southeast Asian descent, it demonstrates intrafamilial phenotypic variability, and confirms that atypical phenotypes are associated with compound heterozygosity.
\end{abstract}

RÉSUMÉ: Fratrie de Malaysie atteinte d'ataxie de Friedreich et de chorée: description d'une nouvelle délétion dans le gène de la frataxine. Introduction: L'ataxie de Friedreich (AF1) résulte la plupart du temps de la présence à l'état homozygote d'une expansion du triplet GAA dans le premier intron du gène de la frataxine. Cette maladie a été observée chez des individus d'origine européenne, Nord africaine, du Moyen Orient et de l'Inde, mais n'a jamais été rapportée chez des populations de l'Asie du Sud-Est. Chez environ $4 \%$ des patients, il s'agit d'une double hétérozygotie composée. Ces patients ont une expansion du triplet GAAsur un allèle et une mutation ponctuelle sur l'autre. Leur phénotype serait atypique. Objectif: Décrire une nouvelle mutation, une délétion d'un dinucléotide dans le gène de l'AF1, chez deux enfants d'origine malaysienne, le frère et la sœur atteints d'ataxie de Friedreich. Cas cliniques: Un jeune garçon Malaysien âgé de 10 ans, sans antécédents médicaux, a consulté dans un hôpital universitaire de soins tertiaires pour une hyperthermie, de la léthargie, de la céphalée, de la dysarthrie, de la dysphagie, du vertige et de l'ataxie apparus au cours de la semaine précédente. L'examen neurologique a montré de la dysarthrie, de l'ataxie, une légère faiblesse généralisée et des mouvements choréiformes de la langue et des mains. Les réflexes étaient absents et un Babinski bilatéral était présent. Sa sœur de neuf ans avait une légère ataxie sans autre signe neurologique. Résultats: Les épreuves de génétique moléculaire ont montré que les deux enfants étaient des doubles hétérozygotes, un allèle étant porteur d'une expansion du triplet GAAet l'autre allèle d'une nouvelle délétion d'un dinucléotide. Conclusions: Nous décrivons une nouvelle délétion d'un dinucléotide dans le premier exon du gène de la frataxine chez deux enfants, le frère et la sœur, atteints d'AF1. De plus, il s'agit du premier cas d'AF1 rapporté dans une famille originaire du Sud-Est Asiatique. Ces cas illustrent la variabilité phénotypique intrafamiliale et confirment que des phénotypes atypiques sont associés à la double hétérozygotie composée.

Can. J. Neurol. Sci. 2004; 31: 383-386

Friedreich ataxia (FRDA1) is an autosomal recessive condition characterized by progressive limb ataxia, cerebellar dysarthria, absent reflexes, loss of vibration and proprioception and pyramidal signs. ${ }^{1}$ Two thirds of FRDA1 patients also have scoliosis, pes cavus and cardiomyopathy.,3 Typically, the disease presents gradually over months to years.
From the Division of Neurology (SDS); Biotechnology Laboratory (SDS, BIS, TPS); Brain Research Center (SDS); University of British Columbia, Dept. of Medical Genetics (SPY); Dept. of Pediatrics (JH, KS); B.C. Children's Hospital, Vancouver, B.C., Canada.

ReCeived July 24, 2003. ACCEPTED infinalform JANUARY 15, 2004. Reprint requests to: Siân Spacey, Neurology and Neurogenetics, Rm. S-127, 2211 Wesbrook Mall,UBC Hospital, Vancouver. B.C., V6T2B5 Canada. 


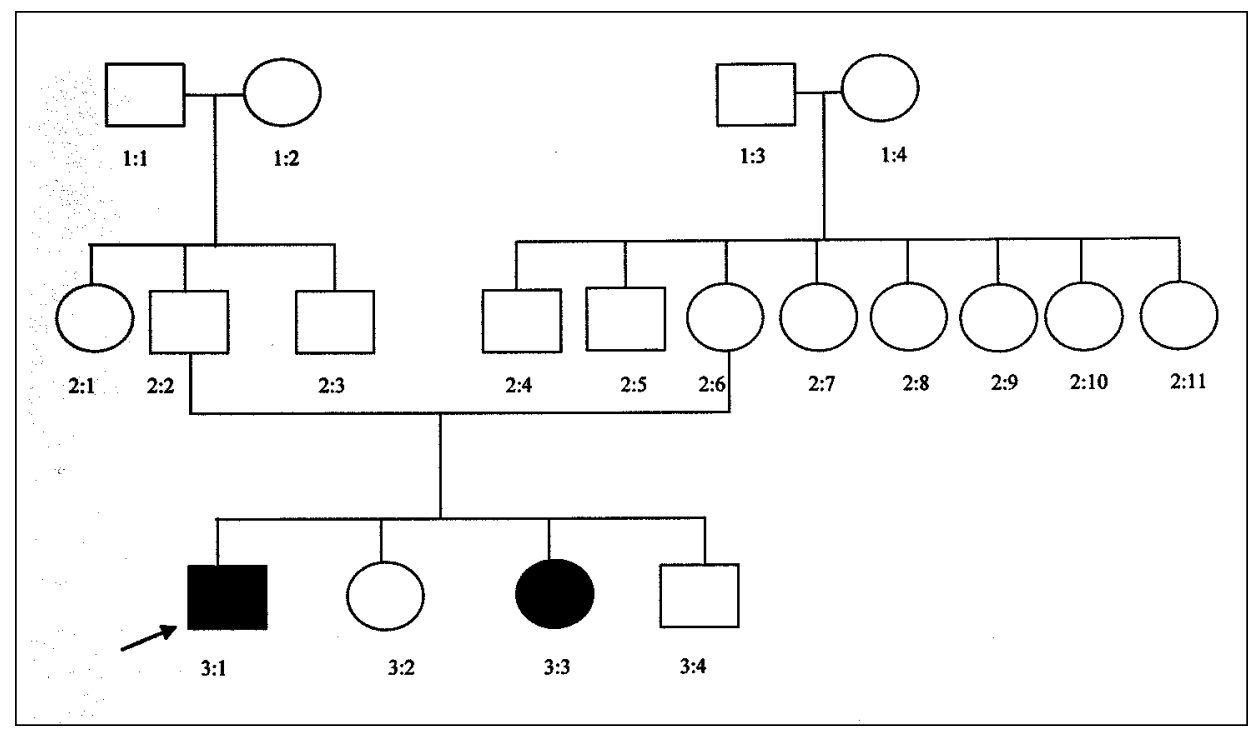

Figure: Pedigree of FRDA1 family. The circles represent females, the squares represent males. The black symbols denote individuals affected with Friedreich ataxia. The arrow indicates the proband.

The frataxin gene (FRDA gene) has been localized to chromosome $9 \mathrm{q} 13^{4}$ and codes for the frataxin protein, a putative iron transporter that regulates mitochondria iron content. ${ }^{5}$ In approximately $96 \%$ of cases the mutation in FRDA gene is an unstable homozygous expansion of a GAA repeat in the first intron. ${ }^{6}$ The number of repeats in normal individuals ranges from 7 - 60 and in affected individuals from 66 to greater than $1700 .^{7}$ Somatic mosaicism of the GAA expansion has been demonstrated in FRDA1 patients. ${ }^{8,9}$ The GAA expansion that causes FRDA1 has only been reported in individuals of European, North African, Middle Eastern or Indian origin (IndoEuropean and Afro-Asiatic speakers), ${ }^{10}$ it has not been reported in the southeast Asian population. Unusual phenotypic features are more commonly seen in the approximately $4 \%$ of patients with FRDA1 who are compound heterozygotes with a GAA expansion on one allele and a point mutation in the FRDA gene on the other allele. ${ }^{7}$ Phenotypic variation between family members with 2 GAA expansions is $\operatorname{seen}^{11,12}$ but is rarely reported in compound heterozygote families. ${ }^{7,13}$

\section{Methods}

\section{GAA repeat analysis}

Genomic DNAwas isolated from peripheral blood of the two siblings and their parents. The region encompassing the GAA repeat in the FRDA gene was polymerase chain reaction amplified under conditions previously described. ${ }^{6}$ Expanded alleles were then resolved and sized using agarose gel electrophoresis.

\section{Sequence analysis of the FRDA gene}

Exons 1-5a and associated intron/exon boundaries were polymerase chain reaction amplified using intronic primers previously described. ${ }^{6}$ The amplification products were then subjected to automated sequencing using an ABI377 DNA sequencer.

\section{RESULTS}

\section{Case 1}

Patient 3:1 (Figure) a previously healthy 10-year-old Malaysian boy, presented with fever, lethargy, headaches, dysarthria, dysphagia, vertigo and ataxia developing over a one week period. His neurological exam revealed mild choreoform movements of the tongue and hands, mild generalized weakness, absent reflexes and bilateral Babinski signs. Sensory examination demonstrated decreased temperature perception in a glove-stocking distribution, however pinprick, vibration and proprioception were normal. He had dysarthria, marked fingernose and heel-shin ataxia. He walked with a broad based ataxic gait and was unable to tandem walk. There was evidence of thoracolumbar scoliosis and pes cavus. As the fever remitted there was mild but not significant improvement in the ataxia and the chorea remained unchanged. Nerve conduction studies demonstrated a severe generalized peripheral sensory and motor neuropathy with both axonal and demyelinating features. An electrocardiogram (ECG) was normal, but an echocardiogram demonstrated left ventricular hypertrophy. An MRI of the head was normal, however the caliber of the cord from the foramen magnum to the conus was significantly smaller than normal. There was no evidence of glucose intolerance. Levels of very long chain fatty acids, arylsulfatase A, phytanic acid, vitamin E, vitamin B12, cholesterol, triglycerides, hexosaminidase A\&B were all normal, as was the cerebral spinal fluid.

\section{Case 2}

After diagnosis of $3: 1$, the other siblings were assessed. Patient 3:3 is the nine-year-old sister. Retrospectively, her 
parents had noticed that she appeared clumsy over the preceding year. Her neurological exam revealed evidence of finger-nose and heel-shin ataxia and she had difficulty with tandem walking and single leg hopping. Her neurological examination was otherwise normal. There was no evidence of scoliosis or pes cavus. There was no evidence of glucose intolerance. An ECG showed normal sinus rhythm, the ST segments were strikingly flattened and inverted across the precordial leads. An echocardiogram demonstrated concentric left ventricular hypertrophy without outflow obstruction.

\section{Parents}

The siblings are the product of a nonconsanguinous relationship. Both father $(2: 2)$ and mother (2:6) are Malaysian and were clinically unaffected.

\section{Molecular genetic analysis}

Analysis of the GAA repeat in patients 3:1, 3:3, and their father (2:2) revealed single allele expansions of approximately 273 repeats, 256 repeats, and 306 repeats, respectively. All other alleles including those of the mother (2:6) were of normal length.

In patients 3:1 and 3:3 direct sequence analysis of the amplification products revealed a heterozygous TC deletion in the first exon on the unexpanded allele. The deletion of nucleotides 11 and 12 results in a frame shift and a predicted truncated frataxin protein. The TC deletion was also found to be present in the mother but to be absent in the father.

\section{Discussion}

This case is notable for four reasons: it reports a novel dinucleotide deletion in the FRDA gene, it is the first case of FRDA1 described in a family of southeast Asian descent and demonstrates unusual phenotypic features as well as intra familial phenotypic variation.

The novel mutation is a TC deletion located in codon 4 of exon 1 resulting in the deletion of the 11th and 12th nucleotides, a frame shift and a predicted truncated protein. This is the first frame shift dinucleotide deletion reported in the FRDA gene. To date, six other mutations have been described in exon 1.,14 Four involve the first codon and cause disruption of initiation of translation, and two involve either the insertion or deletion of a single nucleotide (C) at position 158 producing a truncated protein. Another mutation in intron 1 has been associated with a loss of frataxin on muscle biopsy. ${ }^{15}$

Friedrich ataxia has not been previously described in the Malaysian population. The GAA expansion in the FRDA gene underlying FRDA1 is thought to arise from a common origin. ${ }^{10}$ Expanded alleles (>66 GAA) and long normal alleles ( < 60 GAA) have not been observed in Southeast Asian populations ${ }^{10}$ and, therefore, FRDA1 would be very rare. As GAA expansions are so uncommon it is not surprising that FRDA1 developed in this Malaysian family as the result of a compound heterozygote mutation.

The phenotype seen in patient 3:1 is unusual for the presence of chorea of the hands and tongue supporting previous claims that compound heterozygosity is associated with unusual phenotypes. ${ }^{7}$ Chorea is an uncommon feature of FRDA1 and has previously been reported in two patients homozygous for the GAA expansion ${ }^{16}$ and in a compound heterozygote who had a deletion in the start codon of exon $1 .^{14}$
Also curious is the intrafamilial phenotypic variation observed in the siblings. The sister had no evidence of chorea and had a slowly progressive ataxia. The parents reported the presentation of a profound progression of ataxia in 3:1 over one week. Clinical findings (scoliosis, pes cavus, reduced reflexes and peripheral sensory loss) indicate that the disease process had been longstanding, but the ataxia, if previously present, was mild as it had not been observed by the parents. Whether this sudden progression is the result of genetic influences, environmental factors or a combination of the two cannot be determined. If the newly described TC deletion in our patient was solely responsible for the phenotype, it would be expected that sibling 3:3 would also present with a sudden progression of ataxia, however her phenotype to date is of the more common slowly progressive form. The difference in expansion size is unlikely to account for the phenotypic differences as the difference in repeat length between the two siblings was only 17 repeats.

The most plausible explanation for the sudden progression of ataxia in 3:1 is an increase in mitochondria demand resulting from the febrile illness he contracted. Diseases resulting from mitochondrial dysfunction are known to rapidly progress with intercurrent fever. It can be hypothesized that the fever increased demand on the mitochondria, one that the dysfunctional mitochondria could not meet resulting in cellular damage and subsequent development of ataxia.

In summary, we describe a novel TC deletion in codon 4 of exon 1 that predicts a truncated frataxin protein. The family described here are of Malaysian descent, a population in whom FRDA1 has not previously been described. ${ }^{10}$ Due to the rarity of the GAA expansion in the southeast Asian population it is not surprising that the affected individuals in this family have compound heterozygote mutations. The proband in this study presented with chorea, an atypical feature of FRDA1 not observed in the sibling, supporting the observation of atypical presentations in compound heterozygotes and intrafamilial phenotypic variability in FRDA1. Sudden progression of ataxia on the background of a febrile illness was observed in the proband. Whether this sudden progression is the result of genetic factors, environmental factors or a combination of the two remains to be determined. We hypothesize that an increase in mitochondria demand provoked by a febrile viral illness may have resulted in decompensation of the mitochondria, accelerated cell death and acute presentation of ataxic features.

\section{ACKNOWLEDGEMENTS}

This work was supported by a grant from the Canadian Institute of Health Research (CIHR) of Canada to T.P. Snutch. TPS is supported by a CIHR Senior Scientist Award.

\section{REFERENCES}

1. Durr A, Cossee M, Agid Y, et al. Clinical and genetic abnormalities in patients with Friedreich ataxia. N Eng J Med 1996;335:11691175 .

2. Harding AE, Hewer RL. The heart disease of Friedreich ataxia: a clinical and electrocardiographic study of 115 patients with an analysis of serial electrocardiographic changes in 30 cases. Q J Med 1983;52:489-502.

3. Harding AE. Friedreich ataxia. A clinical and genetic study of 90 families with an analysis of early diagnostic criteria and interfamilial clustering of clinical features. Brain 1981;104:589-620. 
4. Chamberlain S, Shaw J, Rowland A, et al. Mapping of mutation causing Friedreich ataxia to human chromosome 9. Nature 1988;334:248-250.

5. Babcock M, de Silva D, Oaks R, et al. Regulation of mitochondrial iron accumulation by Yfh1p, a putative homolog of frataxin. Science 1997;276:1709-1712.

6. Campuzano V, Montermini L, Molto MD, et al. Friedreich ataxia: autosomal recessive disease caused by an intronic GAA triplet repeat expansion. Science 1996;271:1423-1427.

7. Montermini L, Kish SJ, Jiralerspong S, et al. Somatic mosaicism for Friedreich ataxia GAA triplet repeat expansions in the central nervous system. Neurology 1997;49:606-610.

8. Machkhas H, Bidichandani SI, Patel PI. A mild case of Friedreich ataxia: lymphocyte and sural nerve analysis for GAA repeat length reveals somatic mosaicism. Muscle Nerve 1998;21:390393.

9. Labuda M, Labuda C, Miranda C, et al. Unique origin and specific ethnic distribution of the Friedreich ataxia GAA expansion. Neurology 2000;54:2322-2324.

10. Cossee M, Durr A, Schmitt M, et al. Friedreich ataxia: point mutations and clinical presentation of compound heterozytgotes. Ann Neur 1999; 45:200-206.
11. McCabe DJH, Ryan F, Moore DP, et al. Typical Friedreich ataxia without GAA expansions and GAA expansions without typical Friedreich ataxia[published correction appears in $\mathrm{J}$ Neurol 2000;247:483]. J Neurol 2000;247:346-355.

12. Kellett MW, Fletcher NA, Wood NW, et al. Trinucleotide (GAA)n repeat expansion in two families with Friedreich ataxia with retained reflexes. J Neurol Neurosurg Psychiatry 1997;63:780783.

13. McCabe DJH, Wood NW, Ryan F, et al. Intrafamilial Phenotypic variability in Friedreich ataxia associated with a G130Vmutation in the FRDA gene. Arch Neurol 2002;59:296-300.

14. Zhu D, Burke C, Leslie A, et al. Friedreich ataxia with chorea and myoclonus caused by a compound heterozygosity for a novel deletion and the trinucleotide GAAexpansion. Mov Disord 2002 2002;17(3):585-589.

15. McCormack ML, Guttmann RP, Schumann M, et al. Frataxin point mutations in two patients with Friedreich ataxia and unusual clinical features. J Neurol Neurosurg Psychiatry 2000;68:661664.

16. Hanna MG, Davis MB, Sweeney MG, et al. Generalized chorea in two patients harboring the Friedreich ataxia gene trinucleotide repeat expansion. Mov Disord 1998;13(2):339-340. 